\title{
Volcanic impacts on the Holocene vegetation history of Britain and Ireland? A review and meta- analysis of the palynological evidence
}

Richard J Payne ${ }^{1}$, Kevin J Edwards ${ }^{2,3}$, Jeff J Blackford ${ }^{4}$

${ }^{1}$ School of Science and the Environment, Manchester Metropolitan University, Chester Street, Manchester M1 5GD, UK

${ }^{2}$ Departments of Geography \& Environment and Archaeology, School of Geosciences, University of Aberdeen, Elphinstone Road, Aberdeen AB24 3UF, UK

${ }^{3}$ Clare Hall and McDonald Institute for Archaeological Research, University of Cambridge, Cambridge, UK

${ }^{4}$ Quaternary Environments and Geoarchaeology Research Group, Geography, University of Manchester, Oxford Road, Manchester M13 9PL, UK

ABSTRACT

Volcanic ash layers show that the products of Icelandic volcanism reached Britain and Ireland many times during the Holocene. Historical records suggest that at least one eruption, that of Laki in $A D$ 1783, was associated with impacts on vegetation. These results raise the question: did Icelandic volcanism affect the Holocene vegetation history of Britain and Ireland? Several studies have used pollen data to address this issue but no clear consensus has been reached. We re-analyse the palynological data using constrained ordination with various representations of potential volcanic impacts. We find that the palynological evidence for volcanic impacts on vegetation is weak but suggest that this is a case of absence of evidence and is not necessarily evidence of absence. To increase the chances of identifying volcanic impacts, future studies need to maximise temporal resolution, replicate results, and investigate a greater number of tephras in a broader range of locations, including more studies from lake sediments.

KEYWORDS: Tephra, Hekla, Volcanic impacts, Pollen, Tephropalynology, Ordination 


\section{INTRODUCTION}

At the end of the 1980s, two important discoveries were made in the Holocene palaeoenvironmental record of Britain and Ireland. In the Irish bog-oak tree-ring record, Baillie and Munro (1988) found clusters of extremely narrow rings close to the inferred age of the Minoan eruption of Santorini (Thera) and interpreted these as evidence for a major and widespread volcanogenic climatic deterioration (first suggested by frost-rings in Californian Bristlecone Pines [LaMarche and Hirschboek 1984]). In northern Scotland, meanwhile, Dugmore (1989) reported the first discovery of Holocene Icelandic tephra (volcanic ash) on the British mainland. This finding was swiftly followed by many others throughout the British Isles as palaeoecologists realized the potential of cryptotephrochronology as an accurate, precise and comparatively inexpensive approach to geochronology (Pilcher and Hall 1992, 1996; Dugmore et al. 1995a; Hall and Pilcher 2002). At least 14 Holocene cryptotephras have been found in Britain and 33 in Ireland (Swindles et al. 2011). At the same time as these discoveries, there was increasing scientific curiosity about the environmental impacts of volcanism with the eruptions of Mount St. Helens (1980) and Pinatubo (1991), and a more general resurgence in interest in catastrophism (Burgess 1989; Marriner et al. 2010). These developments led to an important trend in palynological research through the 1990 s and 2000s - the attempt to use the pollen archive to identify distal volcanic impacts on vegetation (Birks 1994; Buckland et al. 1997). The term tephropalynology has been coined for such studies (Edwards 1996; Lowe and Hunt 2001; Edwards et al. 2004).

Blackford et al. (1992) were the first to investigate the palynological record across a volcanic ash layer at high resolution (Table 1). At two peatland sites in Scotland, these authors showed coincidence between the ca. 4300 BP eruption of Hekla (Hekla-4: Dugmore et al. 1995b; Pilcher et al. 1995a; Zillén et al. 2002) and a widely-reported decline in Pinus pollen. In a subsequent study in northern Ireland, Hall et al. (1994b) found no correlation between the Hekla-4 tephra and changes in Pinus pollen, although interpretation was complicated by the uncertain local presence of pine at their study sites (Edwards et al. 1996; Hall et al. 1996). For a tephra layer in Ireland which may be from Hekla-4, Dwyer and Mitchell (1997) suggested possible evidence for volcanic impacts on local, but not regional pollen and nonpalynological palynomorph (NPP) taxa, while Hall (2003a) found no evidence of significant changes across other Irish tephras. In Scotland, Charman et al. (1995) noted palynological changes associated with some tephras, but not others, and in Ireland Caseldine et al. (1998) suggested variability in apparent palaeoenvironmental response between the same tephra in different profiles. Overall, this literature does not provide a clear answer to the key questions - did volcanic activity affect the 
vegetation history of Britain and Ireland during the Holocene? and if so, how? The aim of this paper is to review and re-analyse this evidence after 20 years of studies in an attempt to assess the strength of the case for volcanic impacts on vegetation and to identify significant practical and methodological issues.

\section{Volcanic impacts on vegetation: what can be expected?}

There is little doubt that volcanoes can have drastic impacts on vegetation. Adjacent to a volcanic source lava, pyroclastic flows and lahars may kill all plant life through a combination of extreme heat, manual breakage and burial (Griggs 1918, 1922). In explosive eruptions, plant life may be killed by the extreme heat and violent winds of a volcanic blast (Griggs 1919, Eggler 1948). Such volcanic impacts and the largely sterile substrates which remain, form the basis of a classic primary succession sequence (Eggler 1941, Fridriksson 1975, 1987, Whittaker et al. 1989, 1992, Grishin et al. 1995). While such volcano-vegetation relationships seem evident in the tephropalynological records from peneproximal sites (Erlendsson et al. 2009) and even further afield (Edwards and Craigie 1998), the zone affected by such proximal impacts is relatively small - generally kilometres to tens of kilometres for Holocene eruptions. A much larger region may be affected by distal impacts through exposure to volcanic ash, volcanic gases, aerosols and volcanically-modified precipitation, and additional volcanic impacts on climate and weather. Tephra may lead to the abrasion of plant surfaces (Griggs 1922, Bjarnason 1991), the inhibition of photosynthesis (Cook et al. 1980, Clarkson and Clarkson 1994) and gas exchange (Eggler 1948), cooling of leaves (Cook et al. 1980), crushing of plant tissues (Eggler 1948, Wilcox 1959, Cook et al. 1980), water-logging (Vucetich and Pullar 1963, Crowley et al. 1994), release of metals (Smith et al. 1983), changes to predation (Wilcox 1959) and disease vulnerability (Cook et al. 1980), all resulting in structural changes in plant community composition (Antos and Zobel 1985, Zobel and Antos 1997). As well as tephra, volcanoes may produce large quantities of gases including $\mathrm{CO}_{2}, \mathrm{SO}_{2}, \mathrm{HCl}$ and $\mathrm{HF}$ (Wilcox 1959, Le Guern et al. 1988, Symonds et al. 1988, Delmelle et al. 2002) which can affect vegetation as a gas, as dry deposition, acidic precipitation, aerosols and adherents to tephra particles (Rose 1977, Oskarsson 1980, Delmelle et al. 2001). Impacts on plants may include lesions and burnt spots extending to total defoliation and plant death (Parnell and Burke 1990, Clarkson and Clarkson 1994, Delmelle et al. 2002). Vegetation may be further affected through volcanic soil acidification (Delmelle et al. 2001, 2002). The largest volcanic eruptions also have the power to modify climate with stratospheric injection of sulphur leading to formation of aerosols which are generally efficient scatterers, but only weak absorbers of radiation at solar wavelengths, with consequent tropospheric cooling (McCormick et al. 
1995). Meteorological and proxy-climate records suggest typical cooling following Holocene eruptions of up to $1-2^{\circ} \mathrm{C}$ for up to five years (Mass and Schneider 1977, Self et al. 1981, Angell and Korshover 1985, Sear et al. 1987, Scuderi 1990, Zielinski 2000, Gervais and MacDonald 2001). Plants in marginal locations may be affected by this cooling, producing changes in community composition which could (conceivably) be represented in the palynological record. Species growing close to a thermal threshold may be limited in flowering, or prevented from producing pollen at all for the period of reduced temperatures. Proximally and in the short-term, volcanic eruptions may also lead to increased precipitation and frequent lightning strikes.

The potential for Icelandic volcanism to produce impacts on vegetation in the British Isles is illustrated by the AD 1783-4 Laki eruption. Abundant historical evidence records plant damage and death consistent with known impacts of volcanic acids and aerosols, particularly in eastern England and Scotland, with similar accounts from throughout western Europe (Thorarinsson 1981, Sigurdsson 1982, Camuffo and Enzi 1995, Grattan and Charman 1994, Grattan and Gilbertson 1994, Grattan and Pyatt 1994, Grattan et al. 1998). Given the potential of volcanic eruptions to produce impacts on vegetation, the presence of Icelandic tephra from many Holocene eruptions suggests the possibility of volcanic impacts on vegetation in Britain and Ireland which could be represented in the palynological record. The existing research, however, is inconclusive, with apparently contradictory evidence and various authors presenting a range of viewpoints.

\section{STATISTICAL ANALYSIS OF PALYNOLOGICAL DATA}

Although the use of quantitative data analysis was advocated in 1994 by Birks, the identification of volcanic impacts in pollen diagrams spanning Holocene tephra layers in Britain and Ireland has been entirely qualitative, being based on observed changes coincident with tephra layers and judgements as to whether any of these exceed natural variability. Here we apply a quantitative approach based on constrained ordination. Pollen percentage summary diagrams from published palynological analyses across tephra layers were digitised and compiled. Almost all such diagrams are from peatlands.

A detrended canonical correspondence analysis (DCCA) with depth as the sole explanatory variable was used to determine compositional gradient lengths. As these gradients were short $(<1$ standard deviation), ordination methods based on a linear species response are most appropriate. Redundancy analysis (RDA), the constrained form of principal components analysis (PCA), was used in all 
subsequent analyses. Pollen data were square-root transformed and double centring of samples and variables was applied. In order to account statistically for long-term processes occurring through the full duration of the profiles, depth was treated as a co-variable in all analyses as a surrogate for time. Stratigraphically-constrained Monte Carlo permutation tests (999 permutations) were used to test the significance of the applied models. All ordinations used CANOCO vers. 4.53 (Ter Braak and Šmilauer 19972004).

Previous studies have taken a variety of approaches to the representation of a volcanic impact in an ordination of palaeoecological data. We tested four contrasting models:

i) The simplest model considers the difference between the pollen assemblages prior to and following emplacement of the tephra layer, modelled in CANOCO as a before (0) and after (1) dummy variable with the division placed at the peak tephra concentration. This approach makes the assumption of a lasting impact with no recovery within the period spanned by the profile. This will only be valid where recovery takes longer than the remaining period spanned by the profile, or where the impact leads to a permanent vegetation change.

ii) A more sophisticated method is to model the onset and recovery from a volcanic impact. Lotter and Birks (1993) proposed an approach based on an exponential decay curve. The variable $(x)$ is assigned a value of 0 below the tephra, a value of 100 at the tephra peak decreasing as $\exp ^{x-\alpha t}$ above the tephra where $\alpha$ is the decay coefficient and $\mathrm{t}$ is sample time after the tephra peak. The model thereby assumes an impact starting coincident with the tephra peak and declining rapidly with time. Lotter and Birks (1993) used a value of $\alpha=0.5$. We varied $\alpha$ between 0.1 and 0.7, but this did not change the (non-) significance of the results. Results are reported using $\alpha=0.5$ for comparison with previous studies. Where evidence of impacts is found in multiple profiles, varying this coefficient might be a useful approach to examine differences in the duration of impact.

iii) The above model assumes an instantaneous start to a volcanic impact which, while perhaps valid for the context in which it was first proposed (diatoms in lacustrine sediments), is arguably not appropriate for pollen in peat profiles. The issue is one of taphonomy - Clymo and Mackay (1987) and Rowley and Rowley (1956) have experimentally demonstrated substantial post-depositional movement of pollen through peat profiles. If a volcanic event caused a short-lived increase in pollen deposition of a taxon we would expect some of that additional pollen to be transported into the under- and over-lying peat. An alternative 
volcanic impact model therefore takes account of this taphonomic dimension using an exponential decay curve as above but with $x$ declining similarly both above and below the tephra peak.

iv) A final approach contrasts with the above models. Instead of using a conceptual construct, the tephra concentration profile is used as explanatory variable. This approach has been used in some palaeolimnological studies as volcanic impacts may be directly due to the presence of tephra in the lake (Barker et al. 2000). In these records the concentration profile represents the post-depositional taphonomy of tephra shards (Payne and Gehrels 2010) and there is no probable intrinsic reason for it to be related to the pattern and timing of any volcanic impact on vegetation. However, if the taphonomy of tephra shards and pollen grains were equivalent (see discussion below) then the tephra concentration profile might be a useful indicator of how a short-lived change in pollen deposition would be represented (Hall and Pilcher 2002).

All these models simulate the pattern of a volcanic impact, but do not make fixed assumptions about the mode of impact; they are applicable to both direct and indirect forcing mechanisms. All models were tested for all datasets with the exception of tephra concentration profiles which were not available for some profiles. Where more than one tephra was present in a sequence, all were incorporated in a single analysis. We included the full length of the published profiles, hence spanning differing time periods in different records (Table 1). Analyses make no correction for taxonomic resolution and are necessarily based only on major pollen types for most profiles.

\section{DISCUSSION OF RESULTS}

\section{Limitations of the evidence}

Before discussing the results of our analyses, brief consideration is given to the limitations of the available evidence. The published diagrams include differing numbers of taxa: while some include a large proportion (e.g. 55 taxa in Weir 1995), others are much more selective (e.g. 19 taxa in the Slieve Meelbeg site of Hall et al. 1994a). The taxonomic resolution varies with some differentiating taxa grouped by other authors (e.g. Gramineae/Cerealia) and studies present different selections of 'important' taxa (in the case of Dwyer \& Mitchell [1997] including some NPPs). The digitisation process is 
likely to introduce both minor systematic offsets and small random errors into the data, particularly with rare taxa- abundances marked with a ' + ' symbol in pollen diagrams have generally been recorded as zero. Sampling resolution and profile length also vary between studies and are likely to affect our ability to identify any volcanic impacts. Several of the studies we analyse were not primarily focused on the identification of any volcanic impacts and pollen diagrams are likely to have been constructed in the light of the research questions of primary interest for the study.

Despite such acknowledged limitations, we believe that the results are adequate to address the fundamental question of whether there is sound palynological evidence for volcanic impacts on vegetation history. To consider the issue of whether exclusion of rare taxa affects results, we compared more- and less-detailed version of the records for Hekla-4 at Loch Lèir and Sluggan Bog. No changes were found in the significance of results. Even summary diagrams which include relatively limited numbers of taxa typically encompass the vast majority of all pollen grains. Differences in the published studies would render it difficult to assess the spatial extent of any volcanic impacts, but as our primary question is whether there is any robust evidence for volcanic impacts such differences are not critical to our study.

Data analysis

Volcanic impact models explain a significant proportion of variance in four profiles (Table 2): the Croaghaun East site of Dwyer and Mitchell (1997), the Portmagee site of Hall (2003b), the Dallican Water site of Bennett et al. (1992) and the Altnabreac site of Blackford et al. (1992).

In the case of Croaghaun East, Dwyer and Mitchell (1997) present separate pollen diagrams for regional and local taxa, the latter including some non-pollen palynomorphs such as the testate amoeba Amphitrema flavum (Archerella flavum). Analyses were conducted on each of these records separately and on a combined record incorporating both 'regional' and 'local' taxa as defined in the original paper. Significant relationships were identified in all three of these datasets using the simplest 'before/after' model only. The largest proportion of variance was explained in the regional data with differences between the assemblages above and below the tephras largely accounted for by much reduced Pinus and increased Fraxinus above the twin tephras. In the local record, differences include increased Cyperaceae, Narthecium ossifragum, Sphagnum and NPPs type 16 and 28 above the tephras. The changes are both pronounced and coincident with the tephras, but there is no return towards prior conditions in the subsequent ca. 400 years of the record, and non-significant results are obtained when 
using models which assume a recovery. The authors suggest their record might represent volcanic impacts but we believe this is unlikely. The profile is of relatively low temporal resolution (c. 70 years between samples) and modern ecological studies do not indicate distal volcanic effects lead to such a lasting impact, although this is perhaps possible if the temporary impacts allow an invasive succession. We suggest that this result may be more likely attributable to some broadly coincident non-volcanic environmental change, in this case a longer-term change to wetter climatic conditions. For Portmagee, the 'before/after' model explained around a third of total variance with moderate significance $(p=$ 0.03). The changes detected in the ordinations are a reduction in Corylus and an increase in Gramineae (Poacaeae) up the core. These changes are both distinct and coincident with the tephra layer, although there is no subsequent return to prior conditions and sampling resolution is low. Other models did not produce a significant result. A human impact is a possible alternative explanation, with Corylusdominated woodland being replaced by grassland.

For Altnabreac, three models explain significant variance: tephra concentration, simple exponential decay and the 'peaked' double exponential decay model, of which the latter explains the most variance. In this case the significant result is driven by a substantial peak in Sphagnum coincident with the tephra peak - if this taxon is removed all analyses for each model lose significance. Other notable changes broadly coincident with the tephra include reduced Pinus and an increase in Cyperaceae pollen.

For Dallican Water a moderate proportion of variance is explained with reasonable significance $(\mathrm{P}=0.02)$ by the 'before/after' model. In this profile there are three distinct tephra peaks, the lowest $(704 \mathrm{~cm}$ ) probably representing the early Holocene Saksunarvatn tephra. The upper two peaks (524 and $504 \mathrm{~cm}$ ) are found relatively close to each other and may be either two distinct tephra layers or one layer with complex distribution. Probably at least one of these tephras is Hekla-4. The early Holocene tephra lies close to a zone boundary and coincides with many changes including a decline in Salix and first detection of Quercus and UImus pollen. The $524 \mathrm{~cm}$ tephra coincides with a minor peak in Salix and marks the onset of a short-lived phase until the $504 \mathrm{~cm}$ tephra including a peak in Cyperaceae. There is little distinct change around $504 \mathrm{~cm}$, but above this peak and the zone boundary at $476 \mathrm{~cm}$ there is much less tree pollen. We suggest that the most likely explanation for the significant result is that the 'before/after' variable captures long-term vegetation changes including the early Holocene establishment of trees in an ameliorating climate and mid-Holocene anthropogenic deforestation. We see little reason to suspect volcanic impacts on the vegetation. 
There is no significant relationship in all the other records, including some such as Strath of Kildonan-K1 (Charman et al. 1995) and Loch Lèir (Blackford et al. 1992) which have been suggested to show pollen changes at the time of tephra deposition. In Strath of Kildonan-K1, the tephra profile is rather diffuse, with the most distinct changes (replacement of Coryloid by Cyperaceae pollen) occurring below the tephra peak and therefore not identified as being related to tephra deposition in our analyses. At Loch Lèir, although there is a rise in Cyperaceae and decline in Pinus broadly coincident with the tephra layer, larger changes in these taxa are slightly offset (c. $10 \mathrm{~mm}$ ) from the tephra peak, although tephra mobility in the upper part of a peat profile is a possibility (Payne et al. 2005). We suggest that these records do not provide strong evidence for volcanic impacts.

Pinus decline

The original discussion of putative volcanic impacts by Blackford et al. (1992), and subsequent publications, centred on the possibility of a causal relationship between the decline in Pinus pollen and the Hekla-4 eruption. A mid-Holocene Pinus decline has been widely reported from pollen and macrofossil studies in Britain and Ireland. Earlier research suggested that this event was widespread across Britain, and quite sudden - with Pinus forests replaced by blanket bog around 4000 BP (Bennett 1984). Increasingly, the weight of evidence suggests diversity in both the age and abruptness of this event (e.g. Birks 1975; Bridge et al. 1990; Charman 1994; Pilcher et al. 1995b; Anderson et al. 1998; Lageard et al. 1999; Tipping et al. 2008). At Loch Lèir the data of Blackford et al. (1992) show a two-stage decline in Pinus with the larger changes above the tephra peak. Only in the Altnabreac profile is the Pinus decline almost exactly synchronous with the peak concentration of Hekla-4 tephra and there is a clear decline in Pinus percentage in the sample(s) above the tephra peak. If volcanism caused a change in Pinus pollen production in Britain and Ireland, it would have impacted upon those individuals, or stands of pine, that were already close to a survival threshold. Other trees may have been more robust, while still others may have already declined prior to the Hekla-4 event as a response to a longer-term trend towards wetter conditions (e.g. as at Garry Bog; Hall et al. 1994b) or a cessation in the existence of unusually dry bog surfaces (Gear and Huntley 1991). The possibility of an impact of volcanism on Pinus growth in the region of the Altnabreac site cannot be excluded, but evidence for a more regional volcanically-induced decline in Pinus is weak. 
Evidence of absence or absence of evidence?

Overall this analysis of palynological data provides very limited support for vegetation change consistent with a possible volcanic impact coincident with tephra deposition. The most convincing evidence is from the Altnabreac site (Blackford et al. 1992) where there is a distinct peak in Sphagnum coincident with the tephra layer. Sphagnum might be expected to increase in abundance in response to a cooler climate or increased local moisture but to be deleteriously affected by acidity, the physical impact of tephra or leached metals (Ferguson et al. 1978, 1980; Gorham et al. 1984; Lee et al. 1987). It must be cautioned that this is a change in one taxon at one site and should not be over-interpreted. Although the palynological evidence for volcanic impacts overall is weak, absence of evidence is not necessarily evidence of absence and these results should not be taken to exclude the possibility of volcanic impacts on vegetation.

Volcanic impacts and critical loads

In discussions of possible drivers for putative volcanic impacts in the palynological record, Grattan and Gilbertson (1994) and Grattan et al. (1999) proposed an approach based on the use of critical loads - levels of pollution exposure below which impacts are not known to occur (Nilsson and Grennfelt 1988) and currently set at an effective rainfall pH of 4.4 for UK peatland soils (UK National Focal Centre 2004). Grattan et al. (1999) used extrapolated tephra concentrations in Ireland to state that 'If it is accepted that, at this distance from eruption source, the volume of adsorbed volatiles approached the mass of the [Hekla-4] tephra (Oskarsson 1980), then no less than 50 times the annual critical load for the Irish sediments may have been deposited in one very brief period of time', implying ecological impacts which might be detectable in the palynological record. This reasoning is problematic. Firstly exceedance of a critical load represents the potential for damage to occur but is not a quantitative estimate of damage (UK National Focal Centre 2004), and certainly not an indication of damage which would be detectable using the relatively insensitive tool of palynology. Critical loads are based on studies of impacts of long-term chronic pollution exposure - a quite different case from the exposure of an unpolluted ecosystem to a brief pollution episode. The critical load is an equilibrium concept and gives no information on the timescales for damage (UK National Focal Centre 2004). Although a deposition event 'fifty times the critical load' might be associated with ecological impacts, the use of critical loads is largely inappropriate in this context. 
To address the impact of such brief pollution episodes, specific experiments are required. Payne and Blackford (2005) tested the deposition scenario proposed by Grattan at al. (1999) for peatlands in Ireland and found no detectable changes in peatland plant communities. When this scenario was rescaled to match the maximum tephra deposition found in northern Scotland, significant impacts were noted. This suggests an important but overlooked point: the scale of tephra deposition in Scotland is frequently much greater than that in Ireland and if impacts are in any way related to tephra-loading, then it is possible for the impacts in these two areas to be quite distinct. However, there is also an issue with the assumption that tephra mass is equal to acid mass as used by Grattan et al. (1999), which appears to be based on a misreading of Oskarsson (1980). Oskarsson stated that 'the mass distribution of soluble fluorine ... approaches the mass distribution of the tephra at longer distances', not that the mass of fluorine approaches that of tephra. In the most distal sample analysed, leached fluorine mass is only $0.1 \%$ of tephra mass (Table 4 in Oskarsson 1980). The Oskarsson paper therefore suggests that fluorine mass is much less than is assumed by Grattan et al. (1999) and provides no information at all on acidity per se. Although Grattan et al. proposed this model as a first approximation, both the scale of acid-loading and the use of a critical loads approach to assess the impacts of that loading are questionable.

The nature of tephropalynological evidence and recommendations for future research.

A tephropalynological approach to the study of past volcanic impacts on vegetation has a number of limitations. The most critical of these is the fundamental inability to identify cause-effect relationships. Changes in pollen concentration or relative abundance coincident with a tephra layer may represent volcanically-induced change, but it is impossible to exclude the possibility of coincident nonvolcanic changes such as human impacts. The case for volcanic causation is strengthened if changes are found in multiple profiles and these are consistent with changes observed following recent eruptions. As the magnitude and duration of climate change needed to produce palynologically detectable vegetation change is considerably greater than the climatic impact of most Holocene eruptions, the palynological record is more likely to reveal the direct impact of volcanic products on vegetation than volcanic impacts on climate (Grattan and Charman 1994; Grattan et al. 1999). Given that impacts are generally shortlived, very high resolution will be needed to detect any changes. Typically, this would involve millimetrescale sampling, and/or the selection of sites with very high accumulation rates. 
Linking changes in vegetation to volcanic activity in tephropalynology relies on the comparison of pollen and tephra profiles. Both pollen and tephra move vertically through sediments - tephras are not simple homogenous layers but rather zones of high tephra concentration with sometimes complex three dimensional configurations (Dugmore and Newton 1992; Dugmore et al. 1996; Payne and Gehrels 2010), while similar processes also act on pollen (Clymo and Mackay 1987; Rowley and Rowley 1956). In peatlands, particles with different morphologies and densities may undergo differential taphonomy at three stages: i) trapping by different vegetation types; ii) initial post-depositional movement through the living vegetation and acrotelm peat; iii) longer-term post-depositional movement as the vegetation and acrotelm peat decompose and enter the catotelm. The construction and presentation of tephra profiles is essential in tephropalynological studies. Studies in lakes would provide an interesting contrast to the current studies largely restricted to peatlands, but would bring a different suite of taphonomic problems (e.g. allochthonous sediments, differential sinking and sediment focusing [cf. Thompson et al. 1986; Boygle 1999; Edwards and Whittington 2001]).

A disproportionate number of the existing studies have concentrated on the Hekla-4 eruption. We suggest that a wider range of eruptions should be investigated. It may be the most substantial tephra layer in the region, but the Hekla-4 eruption also occurred at the same time as a pre-existing period of environmental change, thus making impacts harder to identify (Hall 2003a). A particularly useful target would be the 1783 Laki eruption for which there is abundant historical evidence for impacts on vegetation: are these represented in the palynological record? The chronology of such studies would not be straightforward as Laki tephra has not been found in the British Isles and so the tephropalynological approach cannot be applied ; very precise dating by other means would be required (early conifer planting might provide useful age markers (cf. Linnard 1971)). The Laki eruption is, however, atypical of Holocene Icelandic eruptions and so other events should also be investigated. A wider range of sites should also be investigated, particularly in northeast Scotland and the Northern Isles as the areas closest to the Icelandic volcanoes and with the most substantial tephra layers (Bennett et al. 1992; Dugmore et al. 1995). 
The 2010 Eyjafjöll eruption has highlighted the susceptibility of modern European life to tephra deposition, even though it was not associated with widespread ecological impacts and was relatively small (Davies et al. 2010). The Laki historical records and evidence from large eruptions around the world suggest that eruptions may be associated with widely dispersed ecological impacts, with implications for agriculture, conservation and ecosystem services such as carbon sequestration (Gauci et al. 2008). Palynological efforts to identify such impacts in the Holocene remain worthwhile, even if previous results have been overwhelmingly negative. Well-designed studies are necessary to address these questions.

\section{Acknowledgments}

We would like to thank Steve Blake for useful discussion and Valerie Hall, Michael O'Connell and an anonymous reviewer for comments on a previous version of the manuscript. 


\section{REFERENCES}

Anderson DE, Binney HA, Smith MA (1998) Evidence for abrupt climatic change in northern Scotland between 3900 and 3500 calendar years BP. Holocene 8: 97-103

Angell J, Korshover J (1985) Surface temperature changes following the six major volcanic episodes between 1780 and 1980. J Clim Appl Meteorol 24: 937-951

Antos J, Zobel D (1985) Plant form, development plasticity and survival following burial by volcanic tephra. Can J Bot 63: 2083-2090

Baillie M, Munro M (1988) Irish tree rings, Santorini and volcanic dust veils. Nature 332: 344-346

Barker P, Telford R, Merdaci O, Williamson D, Taieb M, Vincens A, Gibert E (2000) The sensitivity of a Tanzanian crater lake to catastrophic tephra input and four millennia of climate change. Holocene 10: $303-310$

Bennett KD (1984) The post-glacial history of Pinus sylvestris in the British Isles. Quaternary Sci Rev 3: 133-155

Bennett KD, Boreham S, Sharp MJ, Switsur VR (1992) Holocene history of environment, vegetation and human settlement on Catta Ness, Lunnasting, Shetland. J Ecol 80: 241-273

Birks HH (1975) Studies in the vegetational history of Scotland. IV. Pine stumps in Scottish blanket peats. Phil Trans R Soc B 270: 181-226

Birks HJB (1994) Did Icelandic volcanic eruptions influence the post-glacial vegetational history of the British Isles? Trends Ecol Evol 9: 312-314

Bjarnason ÁH (1991) Vegetation on lava fields in the Hekla area, Iceland. Acta Phytogeogr Suec 77: 1-114 
Blackford J, Edwards K, Dugmore A, Cook G, Buckland P (1992) Icelandic volcanic ash and mid-Holocene Scots pine (Pinus sy/vestris) pollen decline in northern Scotland. Holocene 2: 260-265

Boygle JE (1999) Variability of tephra in lake and catchment sediments, Svínavatn, Iceland. Glob Planet Change 21: 129-149

Bridge MC, Haggart BA, Lowe JJ (1990) The history and palaeoclimatic significance of subfossil remains of Pinus sylvestris in blanket peats from Scotland. J Ecol 78: 77-99

Buckland PC, Dugmore AJ, Edwards KJ (1997) Bronze Age myths? Volcanic activity and human response in the Mediterranean and North Atlantic regions. Antiquity 71: 581-593

Burgess C (1989) Volcanoes, catastrophe and the global crisis of the late second millennium BC. Current Archaeol 10: 325-329

Camuffo D, Enzi S (1995) Impact of clouds of volcanic aerosols in Italy in the past centuries. Nat Hazards 11: $135-161$

Caseldine C, Hatton J, Huber U, Chiverrell R, Woolley N (1998) Assessing the impact of volcanic activity on mid-Holocene climate in Ireland: the need for replicate data. Holocene 8: 105-111

Charman DJ (1994) Late-glacial and Holocene vegetation history of the Flow Country, northern Scotland. New Phytol 127: 155-168

Charman DJ, West S, Kelly A, Grattan J (1995) Environmental change and tephra deposition: the Strath of Kildonan, northern Scotland. J Arch Sci 22: 799-809

Clarkson BD, Clarkson BR (1994) Vegetation decline following recent eruptions on White Island (Whakaari), Bay of Plenty, New Zealand. New Zeal J Bot 32: 21-36

Clymo RS, Mackay D (1987) Upwash and downwash of pollen and spores in the unsaturated surface layer of Sphagnum-dominated peat. New Phytol 105: 175-185 
Cook R, Barron J, Papendick R, Williams G (1980) Impact on agriculture of the Mount St. Helens eruption. Science 211: 16-22

Crowley S, Dufek D, Stanton R, Ryer T (1994) The effects of volcanic ash deposition on a peat-forming environment: Environmental disruption and taphonomic consequences. Palaios 9: 158-174

Davies SM, Larsen G, Wastegård S, Turney CSM, Hall VA, Coyle L, Thordarson T (2010) Widespread dispersal of Icelandic tephra: how does the Eyjafjöll eruption of 2010 compare to past Icelandic events? J Quaternary Sci 25: 605-611

Delmelle P, Stix J, Bourque C, Baxter P, Garcia-Alvarez J, Barquero J (2001) Dry deposition and heavy acid loading in the vicinity of Masaya volcano, a major sulfur and chlorine source in Nicaragua. Environ Sci Technol 35: 1289-1293

Delmelle P, Stix J, Baxter P, Garcia-Alvarez J, Barguero J (2002) Atmospheric dispersion, environmental effects and potential health hazard associated with the low-altitude gas plume of Masaya volcano, Nicaragua. Bull Volcanol 64: 423-434

De Vleeschouwer F, van Vliët Lanoé B, Fagel N (2008) Long term mobilisation of chemical elements in tephra-rich peat (NE Iceland). Appl Geochem 23: 3819-3839

Dugmore A, Newton A (1992) Thin tephra layers in peat revealed by X-radiography. J Arch Sci 19: 163170

Dugmore A (1989) Icelandic volcanic ash in Scotland. Scot Geogr Mag 105: 168-172

Dugmore A, Larsen G, Newton A (1995a) Seven tephra isochrones in Scotland. Holocene 5: 257-266

Dugmore AJ, Newton AJ, Edwards KJ, Larsen G, Blackford JJ, Cook GT (1996) Long-distance marker horizons from small-scale eruptions: British tephra deposits from the AD 1510 eruption of Hekla, Iceland. J Quaternary Sci 11: 511-516 
Dugmore AJ, Shore JS, Cook GT, Newton AJ, Edwards KJ, Larsen G (1995b) Radiocarbon dating tephra layers in Britain and Iceland. Radiocarbon 37: 379-388

Dwyer RB, Mitchell FJG (1997) Investigation of the environmental impact of remote volcanic activity on north Mayo, Ireland, during the mid-Holocene. Holocene 7: 113-118

Eastwood W, Tibby J, Roberts N, Birks H, Lamb H (2002) The environmental impact of the Minoan eruption of Santorini (Thera): statistical analysis of palaeoecological data from Gölhisar, southwest Turkey. Holocene 12: 431-44

Edwards KJ (1996) Tephropalynology associated with archaeological sites in Scotland and Iceland. Abstracts, 9th International Palynological Congress, Houston, Texas: 37

Edwards KJ, Craigie R (1998) Palynological and vegetational changes associated with the deposition of Saksunarvatn ash in the Faroe Islands. Fróđskaparrit 48: 245-258

Edwards KJ, Dugmore AJ, Blackford JJ (2004) Vegetational response to tephra deposition and land-use change in Iceland: a modern analogue and multiple working hypothesis approach to tephropalynology. Polar Rec 40: 113-120

Edwards KJ, Dugmore AJ, Buckland PC, Blackford JJ, Cook GT (1996) Hekla-4 ash, the pine decline in Northern Ireland and the effective use of tephra isochrones: a comment on Hall, Pilcher and McCormac. Holocene 6: 495-496

Edwards KJ, Whittington G (2001) Lake sediments, erosion and landscape change during the Holocene in Britain and Ireland. Catena 42: 143-173

Eggler WA (1941) Primary succession on volcanic deposits in southern Idaho. Ecol Monogr 11: 270-298

Eggler WA (1948) Plant communities in the vicinity of the volcano El Paricutin, Mexico, after two and a half years of eruption. Ecology 29: 415-436 
Erlendsson E, Edwards KJ, Buckland PC (2009) Vegetational response to human colonisation of the coastal and volcanic environments of Ketilsstaðir, southern Iceland. Quaternary Res 72: 174-187

Ferguson P, Lee J, Bell J (1978) Effects of sulphur pollutants on the growth of Sphagnum species. Environ Pollut 16: 151-162

Ferguson P, Lee JA (1980) Some effects of bisulphate and sulphate on the growth of Sphagnum species in the field. Environ Pollut 21: 59-71

Fridriksson S (1975) Surtsey: evolution of life on a volcanic island. Butterworths, London

Fridriksson S (1987) Plant colonization of a volcanic island, Surtsey, Iceland. Arct Alp Res 19: 425-431

Gauci V, Blake S, Stevenson DS, Highwood EJ (2008) Halving of the northern wetland $\mathrm{CH}_{4}$ source by a large Icelandic volcanic eruption. J Geophys Res G 113: G00A11

Gear AJ, Huntley B (1991) Rapid changes in the range limits of Scots Pine 4000 years ago. Science 251: 544-47

Gervais B, MacDonald G (2001) Tree-ring and summer-temperature response to volcanic aerosol forcing at the northern tree-line, Kola Peninsula, Russia. Holocene 11: 499-505

Gorham E, Bayley S, Schindler D (1984) Ecological effects of acid deposition upon peatlands: A neglected field in acid rain research. Can J Fish Aquat Sci 41: 1256-1268

Grattan J, Charman D (1994) Non-climatic factors and the environmental impact of volcanic volatiles: implications of the Laki fissure eruption of AD1783. Holocene 4: 101-106

Grattan J, Gilbertson D (1994) Acid-loading from Icelandic tephra falling on acidified ecosystems as a key to understanding archaeological and environmental stress in northern and western Britain. J Arch Sci 21: 851-859 
Grattan J, Gilbertson D, Charman D (1999) Modelling the impact of Icelandic volcanic eruptions upon prehistoric societies and environment of northern and western Britain, In: Firth C, McGuire W (eds) Volcanoes in the Quaternary, Geological Society, London, Special Publications 161, pp 109-124

Grattan J, Pyatt F (1994) Acid damage to vegetation following the Laki fissure eruption in 1783- an historical review. Sci Tot Environ 151: 241-247

Griggs R (1918) The eruption of Katmai. Nature 2547: 497-499

Griggs R (1919) The character of the eruption as indicated by its effects on nearby vegetation. Ohio J Sci 19: $173-209$

Griggs R (1922) The Valley of Ten Thousand Smokes. National Geographic Society, Washington D.C Grishin SY, del Moral R, Krestov PV, Verkholat VP (1995) Succession following the catastrophic eruption of Ksudach volcano (Kamchatka, 1907). Vegetatio 127: 129-153

Hall VA (1998) Recent landscape change and landscape restoration in Northern Ireland: a tephra-dated pollen study. Rev Palaeobot Palnol 103: 59-68

Hall VA (2003a) Assessing the impact of Icelandic volcanism on vegetation systems in the north of Ireland in the fifth and sixth millennia BC. Holocene 13: 131-138

Hall VA (2003b) Vegetation history of mid- to western Ireland in the 2nd millennium A.D.; fresh evidence from tephra-dated palynological investigations. Veg Hist Archaeobot 12: 7-17

Hall VA, Mauquoy D (2005) Tephra-dated climate- and human-impact studies during the last 1500 years from a raised bog in central Ireland. Holocene 15: 1086-1093

Hall VA, Pilcher JR (2002) Late-Quaternary Icelandic tephras in Ireland and Great Britain: detection, characterization and usefulness. Holocene 12: 223-230 
Hall VA, Pilcher JR, McCormac FG (1993) Tephra-dated lowland landscape history of the north of Ireland, A.D. 750-1150. New Phytol 125: 193-202

Hall VA, McVicker SJ, Pilcher JR (1994a) Tephra-linked landscape history around 2310 BC of some sites in Counties Antrim and Down. Biol Environ (Proc R Ir Acad)94B: 245-253

Hall VA, Pilcher JR, McCormac F (1994b) Icelandic volcanic ash and the mid-Holocene Scots Pine (Pinus sylvestris) decline in the north of Ireland: no correlation. Holocene 4: 79-83

Hall VA, Pilcher JR, McCormac FG (1996) Hekla-4 ash, the pine decline in Northern Ireland and the effective use of tephra isochrones: reply to Edwards, Dugmore, Buckland, Blackford and Cook. Holocene 6: 496-497

Lageard JGA, Chambers FM, Thomas PA (1999) Climatic significance of the marginalization of Scots pine (Pinus sylvestris L.) C. $2500 \mathrm{BC}$ at White Moss. Holocene 9: 321-331

LaMarche V, Hirschboek K (1984) Frost rings in trees as records of major volcanic eruptions. Nature 307: 121-126

Lee JA, Press MC, Woodin S, Ferguson P (1987) Responses to acidic deposition in ombrotrophic mires in the UK, In: Hutchinson TC, Meema KM (eds.) Effects of atmospheric pollutants on forests, wetlands and agricultural ecosystems, NATO ASI Series, Vol. G16, Springer, Berlin, pp 549-560

LeGuern F, Faivre-Pierret RX, Garrec JP (1988) Atmospheric contribution of volcanic sulphur vapor and its influence on the surrounding vegetation. J Volcanol Geoth Res 35: 173-178

Linnard W (1971) Thomas Johnes (1748-1816) pioneer of upland afforestation in Wales. Forestry 44: $135-143$ 
Lotter A, Birks H (1993) The impact of the Laacher See tephra on terrestrial and aquatic ecosystems in the Black Forest, southern Germany. J Quaternary Sci 8: 263-276

Lowe DJ, Hunt JB (2001) A summary of terminology used in tephra-related studies. In: Juvigné, ET, Raynal J-P (Eds) Tephras: Chronology, Archaeology. CDERAD éditeur, Goudet. Les Dossiers de I'ArchéoLogis. 1, pp17-22

Marriner N, Morhange C, Skrimshire S (2010) Geoscience meets the four horsemen? Tracking the rise of catastrophism. Glob Planet Change 74: 43-48

Mass C, Schneider S (1977) Statistical evidence on the influence of sunspots and volcanic dust on longterm temperature records. J Atmos Sci 34: 1995-2004

McCormick MP, Thomason LW, Trepte CR (1995) Atmospheric effects of the Mt Pinatubo eruption. Nature 373: 399-404

Nilsson J, Grennfelt P (1988) Critical loads for sulphur and nitrogen. UNECE/Nordic Council of Ministers, Skokloster, Sweden

Oskarsson N (1980) The interaction between volcanic gases and tephra: flourine adhering to tephra of the 1970 Hekla eruption. J Volcanol Geoth Res 8: 251-266

Parnell R, Burke K (1990) Impacts of acid emissions from Nevado del Ruiz volcano, Colombia, on selected terrestrial and aquatic ecosystems. J Volcanol Geoth Res 42: 69-88

Payne R, Blackford J (2005) Simulating the impacts of distal volcanic products upon peatlands in northern Britain: an experimental study on the Moss of Achnacree, Scotland. J Arch Sci 32: 989-1001

Payne R, Gehrels M (2010) The formation of tephra layers in peatlands: an experimental approach. Catena 81: 12-23 
Pilcher JR, Baillie MGL, Brown DM, McCormac FG, MacSweeney PB, McLawrence AS (1995b)

Dendrochronology of subfossil pine in the north of Ireland. J Ecol 83: 665-671

Pilcher JR, Hall V (1992) Towards a tephrochronology for the Holocene of the north of Ireland. Holocene 2: $255-259$

Pilcher J, Hall V (1996) Tephrochronological studies in northern England. Holocene 6: 100-105

Rose WI (1977) Scavenging of volcanic aerosol by ash: atmospheric and volcanological implications. Geology 5: 621-624

Pilcher J, Hall V, McCormac F (1995a) Dates of Holocene Icelandic volcanic eruptions from tephra layers in Irish peats. Holocene 5: 103-110

Reimer PJ, Baillie MGL, Bard E, Bayliss A, Beck JW, Blackwell PG, Bronk Ramsey C, Buck CE, Burr GS, Edwards RL, Friedrich M, Grootes PM, Guilderson TP, Hajdas I, Heaton TJ, Hogg AG, Hughen KA, Kaiser KF, Kromer B, McCormac FG, Manning SW, Reimer RW, Richards DA, Southon JR, Talamo S, Turney CSM, van der Plicht J, Weyhenmeyer CE (2009) IntCal09 and Marine09 radiocarbon age calibration curves, 050,000 years cal BP. Radiocarbon 51: 1111-1150

Rowley J, Rowley J (1956) Vertical migration of spherical and aspherical pollen in a Sphagnum bog. Proc Minnesota Acad Sci 24: 29-30

Scuderi L (1990) Tree-ring evidence for climatically effective volcanic eruptions. Quaternary Res 34: 6785

Sear C, Kelly P, Jones P, Goodess C (1987) Global surface-temperature responses to major volcanic eruptions. Nature 330: 365-367

Self S, Rampino M, Barbera J (1981) The possible effects of large 19th and 20th century volcanic eruptions on zonal and hemispheric surface temperatures. J Volcanol Geoth Res 11: 41-60 
Sigurdsson H (1982) Volcanic pollution and climate: The 1783 Laki eruption. Eos 63: 601-603

Smith DB, Zielinski RA, Taylor HE, Sawyer MB (1983) Leaching characteristics of ash from the May 18, 1980, eruption of Mount St. Helens volcano, Washington. Bull Volcanol 46: 103-124

Swindles GT, Lawson IT, Savov IP, Connor CB, Plunkett G (2011) A 7000 yr perspective on volcanic ash clouds affecting northern Europe. Geology 39: 887-890

Symonds R, Rose W, Reed M (1988) Contribution of $\mathrm{Cl}^{-}$and $\mathrm{F}^{-}$bearing gases to the atmosphere by volcanoes. Nature 334: 415-418

Ter Braak C, Šmilauer P (1997-2004) CANOCO for Windows. Biometris-Plant Research, The Netherlands

Thompson, R., Bradshaw, H.W. and Whitley, J.E. (1986) The distribution of ash in Icelandic lake sediments and the relative importance of mixing and erosion processes. J Quaternary Sci 1: 3-11

Thorarinsson S (1981) Greetings from Iceland: Ash-falls and volcanic aerosols in Scandinavia. Geogr Ann 63A: $109-118$

Tipping R, Ashmore P, Davies AL, Haggart BA, Moir A, Newton A, Sands R, Skinner T, Tisdall E (2008) Prehistoric Pinus woodland dynamics in an upland landscape in northern Scotland: the roles of climate change and human impact. Veg Hist Archaeobot 17: 251-267

UK National Focal Centre (2004) Update to: The status of UK critical loads. Critical loads methods, data and maps. CEH Monkswood, UK

Vucetich CG, Pullar WA (1963) Ash beds and soils in the Rotorua District. Proc NZ Ecol Soc 10: 2-9

Weir DA (1995) A palynological study of landscape and agricultural development in County Louth in the second millennium BC and the first millennium AD. In: Discovery Programme Reports 2. Project Results 1993. Royal Irish Academy/Discovery Programme, Dublin, pp 77-126 
Whittaker RJ, Bush MB, Richards K (1989) Plant recolonization and vegetation succession on the Krakatau Islands, Indonesia. Ecol Monogr 59: 59-123

Whittaker RJ, Walden J, Hill J (1992) Post-1883 ash fall on Panjang and Sertung and its ecological impact. GeoJournal 28: 153-171

Wilcox R (1959) Some effects of recent ash falls with especial reference to Alaska. Ohio J Sci 49: 409-475

Zielinski G (2000) Use of paleo-records in determining variability within the volcanism-climate system. Quaternary Sci Rev 19: 417-438

Zillén LM, Wastegård S, Snowball IF (2002) Calendar year ages of three mid-Holocene tephra layers identified in varved lake sediments in west central Sweden. Quaternary Sci Rev 21: 1583-1591

Zobel D, Antos J (1997) A decade of recovery of understorey vegetation buried by volcanic tephra from Mount St Helens. Ecol Monogr 67: 317-344 
Fig. 1. Tephropalynological study sites in Britain and Ireland included in this study. Site codes: DWDallican Water, AL- Altnabreac and Loch Lèir, SK- Strath of Kildonan, GA-Garry Bog, FA- Fallahogy, BEBallyscullion East, SL- Sluggan Bog, SM- Slieve Meelbeg, RB- Redbog, CE- Croaghaun East, CO- Corlea, MG- Mongan Bog, MV- Moneyveagh Bog, MN- Monaincha Bog, PM- Portmagee Bog. Iceland is $\sim 500 \mathrm{~km}$ NW of the NW corner of this map.

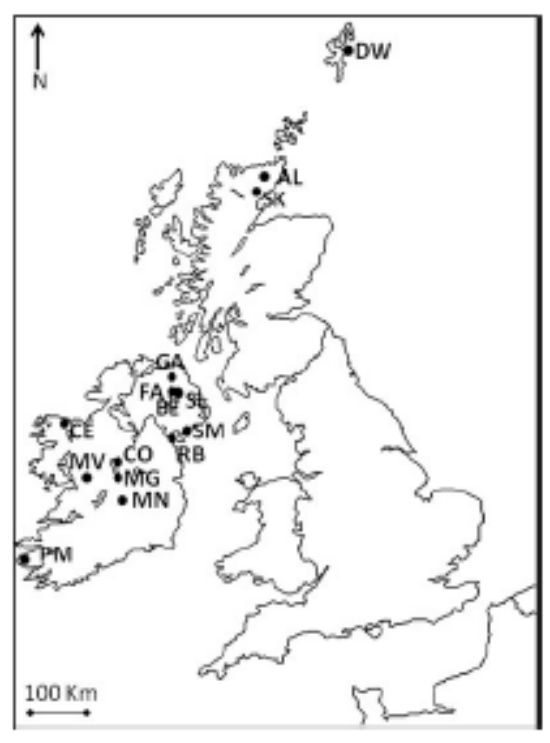


Table 1. Key details of tephropalynological profiles from Britain and Ireland. All dates are historical or calibrated radiocarbon years based on the chronology in the original paper. For Bennett et al. (1992) new calibration was carried out with CALIB6.0 based on the IntCal09 data (Reimer et al. 2009). Due to the limited dating evidence, the estimated duration and temporal resolution of several records should be regarded as highly approximate. All interpretation is generally that of the original author(s) except where no information is presented. Sampling resolution reflects the combination of the thickness of each sampled depth and, where samples are non-contiguous, the gap between samples. WD-EPMA= wavelength-dispersive electron probe microanalysis, ED-EPMA= energy-dispersive electron probe microanalysis.

\begin{tabular}{|c|c|c|c|c|c|c|c|}
\hline Authors & Site/profile & $\begin{array}{l}\text { Dating } \\
\text { approach }\end{array}$ & $\begin{array}{l}\text { Duration of } \\
\text { record (years; } \\
\text { to nearest 100) }\end{array}$ & $\begin{array}{l}\text { Sampling } \\
\text { resolution } \\
(\mathrm{mm})\end{array}$ & $\begin{array}{l}\text { Approximate } \\
\text { temporal } \\
\text { resolution } \\
\text { (years; to } \\
\text { nearest 10) }\end{array}$ & $\begin{array}{l}\text { Tephra } \\
\text { identification } \\
\text { approach }\end{array}$ & Tephra \\
\hline \multirow[t]{3}{*}{ Bennett et al. (1992) } & \multirow[t]{3}{*}{ Dallican Water } & \multirow[t]{3}{*}{ Radiocarbon } & \multirow[t]{3}{*}{$\sim 8500$} & \multirow[t]{3}{*}{$40-80$} & \multirow[t]{3}{*}{$\sim 30$} & \multirow[t]{3}{*}{ WD-EPMA } & $\begin{array}{l}\text { Probable } \\
\text { Saksunarvatn }\end{array}$ \\
\hline & & & & & & & Hekla-4? \\
\hline & & & & & & & Uncertain \\
\hline Charman et al. (1995) & $\begin{array}{l}\text { Strath of Kildonan } \\
\text { K1 }\end{array}$ & $\begin{array}{l}\text { By reference to } \\
\text { regional pollen } \\
\text { record }\end{array}$ & $400 y ?$ & 10 & $\sim 40 ?$ & - & Uncertain \\
\hline Charman et al. (1995) & $\begin{array}{l}\text { Strath of Kildonan } \\
\text { K2 }\end{array}$ & $\begin{array}{l}\text { By reference to } \\
\text { regional pollen } \\
\text { record }\end{array}$ & $400 y ?$ & 10 & $\sim 40 ?$ & $\begin{array}{l}\text { Based on } \\
\text { inferred age }\end{array}$ & $\begin{array}{l}\text { Possible } \\
\text { Hekla-4 }\end{array}$ \\
\hline Charman et al. (1995) & $\begin{array}{l}\text { Strath of Kildonan } \\
\text { K3 }\end{array}$ & $\begin{array}{l}\text { By reference to } \\
\text { regional pollen } \\
\text { record }\end{array}$ & $400 y ?$ & 10 & $\sim 40 ?$ & - & Uncertain \\
\hline \multirow[t]{2}{*}{ Hall (1998) } & \multirow[t]{2}{*}{ Garry Bog } & \multirow{2}{*}{$\begin{array}{l}\text { By reference to } \\
\text { historically } \\
\text { dated tephras }\end{array}$} & \multirow[t]{2}{*}{$\sim 800$} & \multirow[t]{2}{*}{10} & \multirow[t]{2}{*}{$\sim 10-20$} & \multirow[t]{2}{*}{ WD-EPMA } & Hekla 1510 \\
\hline & & & & & & & $\begin{array}{l}\text { Öræfajökull } \\
1362\end{array}$ \\
\hline \multirow[t]{2}{*}{ Hall (2003a) } & \multirow[t]{2}{*}{ Fallahogy } & \multirow{2}{*}{$\begin{array}{l}\text { By reference to } \\
\text { radiocarbon } \\
\text { dated tephras }\end{array}$} & \multirow[t]{2}{*}{$\sim 500$} & \multirow[t]{2}{*}{10} & \multirow[t]{2}{*}{$\sim 10$} & \multirow[t]{2}{*}{ WD-EPMA } & Lairg- A \\
\hline & & & & & & & Lairg-B \\
\hline \multirow[t]{3}{*}{ Hall (2003a) } & \multirow[t]{3}{*}{ Sluggan Bog } & \multirow[t]{3}{*}{ Radiocarbon } & \multirow[t]{3}{*}{$\sim 1100$} & \multirow[t]{3}{*}{10} & \multirow[t]{3}{*}{$\sim 10$} & - & Uncertain \\
\hline & & & & & & \multirow[t]{2}{*}{ WD-EPMA } & Lairg- A \\
\hline & & & & & & & Lairg-B \\
\hline Hall $(2003 b)^{b}$ & Portmagee Bog & $\begin{array}{l}\text { By reference to } \\
\text { radiocarbon } \\
\text { dated tephra }\end{array}$ & $\sim 1000$ & 20 & $\sim 60$ & WD-EPMA & Hekla 1104 \\
\hline \multirow[t]{2}{*}{ Hall $(2003 b)^{b}$} & \multirow[t]{2}{*}{ Moneyveagh Bog } & \multirow{2}{*}{$\begin{array}{l}\text { By reference to } \\
\text { historically } \\
\text { dated tephras }\end{array}$} & \multirow[t]{2}{*}{$\sim 1000$} & \multirow[t]{2}{*}{10} & \multirow[t]{2}{*}{$\sim 20$} & WD-EPMA & Hekla 1104 \\
\hline & & & & & & & $\begin{array}{l}\text { Öræfajökull } \\
1362\end{array}$ \\
\hline Hall $(2003 b)^{b, k}$ & Monaincha Bog & $\begin{array}{l}\text { By reference to } \\
\text { historically } \\
\text { dated tephras }\end{array}$ & $\sim 900$ & 10 & $\sim 20$ & WD-EPMA & Hekla 1104 \\
\hline Hall et al. (1994b) & Garry Bog & $\begin{array}{l}\text { By reference to } \\
\text { radiocarbon } \\
\text { dated tephra }\end{array}$ & $\sim 300$ & 5 & $\sim 10$ & WD-EPMA & Hekla-4 \\
\hline Hall et al. (1994b) & Sluggan Bog & Radiocarbon & $\sim 300$ & 5 & $\sim 10$ & WD-EPMA & Hekla-4 \\
\hline Blackford et al. (1992) & Altnabreac & $\begin{array}{l}\text { By reference to } \\
\text { radiocarbon } \\
\text { dating in nearby } \\
\text { core }\end{array}$ & $\sim 300$ & $1-4$ & $\sim 5-30$ & $\begin{array}{l}\text { By reference } \\
\text { to WD-EPMA } \\
\text { in nearby } \\
\text { core }\end{array}$ & Hekla-4 \\
\hline Blackford et al. (1992) & Loch Lèir & $\begin{array}{l}\text { By reference to } \\
\text { radiocarbon } \\
\text { dating in nearby }\end{array}$ & $\sim 200$ & $1-4$ & $\sim 5-20$ & $\begin{array}{l}\text { By reference } \\
\text { to WD-EPMA } \\
\text { in nearby }\end{array}$ & Hekla-4 \\
\hline
\end{tabular}




\begin{tabular}{|c|c|c|c|c|c|c|c|}
\hline & & core & & & & core & \\
\hline $\begin{array}{l}\text { Dwyer and Mitchell } \\
\text { (1997) }\end{array}$ & Croaghaun East & Radiocarbon & $\sim 1400$ & 50 & $\sim 70$ & WD-EPMA & Hekla-4?* \\
\hline Caseldine et al. (1998) & Corlea I & $\begin{array}{l}\text { By reference to } \\
\text { radiocarbon } \\
\text { dating in nearby } \\
\text { cores }\end{array}$ & $\sim 800$ & $20-80$ & $\sim 10$ & $\begin{array}{l}\text { By reference } \\
\text { to ED-EPMA } \\
\text { in nearby } \\
\text { core and } \\
\text { probable } \\
\text { date }\end{array}$ & Hekla-4? \\
\hline Caseldine et al. (1998) & Corlea II & $\begin{array}{l}\text { Single } \\
\text { radiocarbon } \\
\text { date and } \\
\text { analogy to } \\
\text { other dates } \\
\text { from nearby }\end{array}$ & $\sim 1000$ & 20 & $\sim 10$ & ED-EPMA & Hekla-4? \\
\hline Caseldine et al. (1998) & Corlea V & $\begin{array}{l}\text { By reference to } \\
\text { radiocarbon } \\
\text { dating in nearby } \\
\text { cores }\end{array}$ & $\sim 1000$ & $10-40$ & $\sim 10$ & $\begin{array}{l}\text { By reference } \\
\text { to ED-EPMA } \\
\text { in nearby } \\
\text { core and } \\
\text { probable } \\
\text { date }\end{array}$ & Hekla-4? \\
\hline Hall et al. $(1994 a)^{b}$ & Slieve Meelbeg & $\begin{array}{l}\text { By reference to } \\
\text { radiocarbon } \\
\text { dated tephra }\end{array}$ & $100 ?$ & 10 & $\sim 10$ & WD-EPMA & Hekla-4 \\
\hline \multirow[t]{2}{*}{ Hall et al. (1993) } & \multirow[t]{2}{*}{ Sluggan Bog } & \multirow[t]{2}{*}{ Radiocarbon (?) } & \multirow[t]{2}{*}{$\sim 700$} & \multirow[t]{2}{*}{10} & \multirow[t]{2}{*}{$\sim 20$} & \multirow[t]{2}{*}{ WD-EPMA } & $\begin{array}{l}\text { c. AD860 } \\
\text { tephra }\end{array}$ \\
\hline & & & & & & & $\begin{array}{l}\text { c. AD1088 } \\
\text { tephra }\end{array}$ \\
\hline \multirow[t]{2}{*}{ Hall et al. (1993) } & \multirow[t]{2}{*}{ Fallahogy } & \multirow{2}{*}{$\begin{array}{l}\text { By reference to } \\
\text { radiocarbon } \\
\text { dated tephra (?) }\end{array}$} & \multirow[t]{2}{*}{$\sim 600$} & \multirow[t]{2}{*}{$10-20$} & \multirow[t]{2}{*}{$\sim 10-20$} & \multirow{2}{*}{$\begin{array}{l}\text { Appearance } \\
\text { and inferred } \\
\text { age }\end{array}$} & $\begin{array}{l}\text { c. AD860 } \\
\text { tephra }\end{array}$ \\
\hline & & & & & & & $\begin{array}{l}\text { c. AD1088 } \\
\text { tephra }\end{array}$ \\
\hline \multirow[t]{2}{*}{ Hall et al. (1993) } & \multirow[t]{2}{*}{ Ballyscullion East } & \multirow{2}{*}{$\begin{array}{l}\text { By reference to } \\
\text { radiocarbon } \\
\text { dated tephra (?) }\end{array}$} & \multirow[t]{2}{*}{$\sim 500$} & \multirow[t]{2}{*}{$10-20$} & \multirow[t]{2}{*}{$\sim 20-40$} & \multirow{2}{*}{$\begin{array}{l}\text { Appearance } \\
\text { and inferred } \\
\text { age }\end{array}$} & $\begin{array}{l}\text { c. AD860 } \\
\text { tephra }\end{array}$ \\
\hline & & & & & & & $\begin{array}{l}\text { c. AD1088 } \\
\text { tephra }\end{array}$ \\
\hline \multirow[t]{2}{*}{ Weir (1995) } & \multirow[t]{2}{*}{ Redbog } & \multirow[t]{2}{*}{ Radiocarbon } & \multirow[t]{2}{*}{$\sim 6500$} & \multirow[t]{2}{*}{$10-40$} & \multirow[t]{2}{*}{$\sim 20-90$} & - & Unknown \\
\hline & & & & & & $\begin{array}{l}\text { WD-EPMA } \\
\text { and inferred } \\
\text { age }\end{array}$ & Hekla-4? \\
\hline \multirow[t]{3}{*}{ Hall and Mauquoy (2005) } & \multirow[t]{3}{*}{ Mongan Bog } & \multirow{3}{*}{$\begin{array}{l}\text { By reference to } \\
\text { historically- } \\
\text { dated tephras }\end{array}$} & \multirow[t]{3}{*}{$\sim 1500$} & \multirow[t]{3}{*}{10} & \multirow[t]{3}{*}{$\sim 20$} & \multirow[t]{3}{*}{ WD-EPMA } & Hekla 1947 \\
\hline & & & & & & & $\begin{array}{l}\text { c. AD1600 } \\
\text { tephra }\end{array}$ \\
\hline & & & & & & & Hekla 1104 \\
\hline
\end{tabular}

*Described as twin tephra layers, but in the absence of a tephra concentration profile and EPMA data for both it is impossible to be sure these are not simply two peaks of the same tephra. 
Table 2. Results of redundancy analysis using four models (i-iv) of volcanic impact as an explanatory variable with depth as a co-variable. The percentage variance explained and $P$-values determined by stratigraphically- constrained permutation tests (999 permutations), ns=not significant. No individual tests are significant if applying a Bonferroni correction for multiple-comparisons.

\begin{tabular}{|c|c|c|c|c|}
\hline \multirow[t]{2}{*}{ Data } & \multicolumn{4}{|c|}{ Percent variance explained and $P$-value } \\
\hline & i) Before/after & $\begin{array}{l}\text { ii) } \\
\text { Exponential } \\
\text { decay }\end{array}$ & $\begin{array}{c}\text { iii) } \\
\text { Peaked }\end{array}$ & $\begin{array}{c}\text { iv) } \\
\text { Concentration }\end{array}$ \\
\hline Weir (1995) Redbog II & ns & ns & ns & - \\
\hline Hall et al. (1993) Fallahogy & $\mathrm{ns}$ & ns & ns & - \\
\hline Hall et al. (1993) Sluggan Bog & ns & ns & ns & - \\
\hline Hall et al. (1993) Ballyscullion East & ns & ns & ns & - \\
\hline $\begin{array}{l}\text { Hall and Mauquoy (2005) Mongan } \\
\text { Bog }\end{array}$ & ns & ns & ns & - \\
\hline Hall (1998) Garry Bog & $\mathrm{ns}$ & ns & $\mathrm{ns}$ & - \\
\hline Bennett et al. (1992) Dallican Water & $10.7(P=0.02)$ & ns & ns & ns \\
\hline Blackford et al. (1992) Altnabreac & ns & $23.3(P=0.02)$ & $\begin{array}{c}32.0 \\
(P=0.02)\end{array}$ & $19.7(P=0.02)$ \\
\hline Blackford et al. (1992) Loch Lèir & ns & ns & ns & ns \\
\hline Caseldine et al. (1998) Corlea I & $\mathrm{ns}$ & $\mathrm{ns}$ & ns & ns \\
\hline Caseldine et al. (1998) Corlea II & ns & ns & $\mathrm{ns}$ & ns \\
\hline Caseldine et al. (1998) Corlea V & $\mathrm{ns}$ & ns & ns & ns \\
\hline Charman et al. (1995) K1 & ns & ns & $\mathrm{ns}$ & ns \\
\hline Charman et al. (1995) K2 & $\mathrm{ns}$ & ns & ns & ns \\
\hline Charman et al. (1995) K3 & ns & ns & ns & ns \\
\hline $\begin{array}{l}\text { Dwyer and Mitchell (1997) } \\
\text { Croaghaun East- Regional }\end{array}$ & $31.4(P=0.02)$ & ns & ns & - \\
\hline $\begin{array}{l}\text { Dwyer and Mitchell (1997) } \\
\text { Croaghaun East- Local }\end{array}$ & $13.2(P=0.04)$ & ns & ns & - \\
\hline $\begin{array}{l}\text { Dwyer and Mitchell (1997) } \\
\text { Croaghaun East- Combined }\end{array}$ & $18.9(P=0.02)$ & ns & ns & - \\
\hline Hall et al. (1994b) Garry Bog & ns & ns & ns & - \\
\hline Hall et al. (1994b) Sluggan Bog & $\mathrm{ns}$ & $\mathrm{ns}$ & ns & - \\
\hline Hall et al. (1994a) Slieve Meelbeg & $\mathrm{ns}$ & $\mathrm{ns}$ & ns & ns \\
\hline Hall (2003) Fallahogy & $\mathrm{ns}$ & $\mathrm{ns}$ & $\mathrm{ns}$ & - \\
\hline Hall (2003) Sluggan Bog & ns & ns & $\mathrm{ns}$ & - \\
\hline Hall (2003b) Portmagee Bog & $29.2(P=0.03)$ & ns & $\mathrm{ns}$ & - \\
\hline Hall (2003b) Moneyveagh Bog & ns & ns & $\mathrm{ns}$ & - \\
\hline Hall (2003b) Monaincha Bog & $\mathrm{ns}$ & ns & $\mathrm{ns}$ & - \\
\hline
\end{tabular}

